\title{
What is a Genus in Cypereae: Phylogeny, Character Homology Assessment and Generic Circumscription in Cypereae
}

\author{
A. Muthama Muasya ${ }^{1,2,6}$ - Alexander Vrijdaghs ${ }^{2}$. \\ David A. Simpson ${ }^{3} \cdot$ Mark W. Chase ${ }^{3}$. \\ Paul Goetghebeur ${ }^{4}$ Erik Smets ${ }^{2,5}$ \\ ${ }^{1}$ Botany Department, University of Cape Town, Rondebosch 7700, South Africa \\ ${ }^{2}$ Laboratory of Plant Systematics, K.U. Leuven, Kasteelpark Arenberg 31, BE-3001 Leuven, Belgium \\ ${ }^{3}$ Royal Botanic Gardens Kew, Richmond Surrey TW9 3DS, UK \\ ${ }^{4}$ Department of Biology, Ghent University, K.L. Ledegancksraat 35, B-9000 Ghent, Belgium \\ ${ }^{5}$ National Herbarium of the Netherlands, P. O. Box 9514, NL-2300 RA Leiden, Netherlands \\ ${ }^{6}$ Author for Correspondence; e-mail: muthama.muasya@uct.ac.za \\ Published online: 6 December 2008 \\ (C) The Author(s) 2008. This article is published with open access at Springerlink.com
}

\begin{abstract}
Using a DNA-based tree as the framework, the homology of key taxonomic characters in tribe Cypereae (900 species in 19 genera, the largest of which is Cyperus) is assessed and revisit the question of generic circumscription. Plastid DNA ( $r b c L$ gene, $r p s 16$ intron, $\operatorname{trn} L$ intron and $t r n L-F$ intergenic spacer) sequence matrix for 50 species in 19 genera of Cypereae is analysed using the maximum parsimony algorithm of PAUP. Two major groups are observed: the Ficinia and Cyperus clades. The Ficinia clade includes taxa with a center of diversity in the Cape Floristic Region of South Africa. These are predominantly perennial herbs (with exception of Isolepis, which is predominantly annual) having non-Kranz $\left(\mathrm{C}_{3}\right)$ anatomy and spirally arranged glumes. Species of the Cyperus clade have a predominatly distichous glume arrangement and Kranz anatomy which is either absent $\left(\mathrm{C}_{3}\right)$ or present $\left(\mathrm{C}_{4}\right)$. Cyperus is the core genus in the Cyperus clade, in which 13 additional segregate genera are embedded. These segregate genera differ from typical Cyperus in one or more of a few gross morphological characters. There are no unambiguous characters separating $\mathrm{C}_{3}$ and $\mathrm{C}_{4}$ Cyperus species. The circumscription of Cypereae is broadened to include all taxa with a Cyperus-type embryo and perianth segments. Three taxa possessing perianth segments, namely Hellmuthia membranacea, Scirpus falsus and S. ficinioides, are supported to be closer to Cyperus than to Scirpus.
\end{abstract}

Keywords Cyperus Clade · Ficinia Clade · Life Forms · Hypogynous Scales · Gynophore · Kranz Anatomy · Inflorescence Morphology · Elongation of Filaments · Dispersal Unit · Nutlet Orientation 


\section{Introduction}

Taxa included in tribe Cypereae are annual or perennial herbs that vary in stature from minute to $5 \mathrm{~m}$ tall. Leaves generally have well-developed blades, but are reduced to lobes in some species; there also may be a ligule. Inflorescences are capitate or anthelate. They all have hermaphrodite, trimerous flowers, with each subtended by a papery glume. Glumes are spirally or distichously arranged in the spikelets, apart from some reduced species in which the arrangement is obscure.

Generic classification in tribe Cypereae and subfamily Cyperoideae dates back to Linneaus (1753), who described the genera Scirpus and Cyperus to include all species of Cyperaceae with bisexual flowers, and distinguished by the spiral versus distichous glume arrangement in Scirpus and Cyperus respectively. The broad circumscription of Scirpus, based on common and widespread characters, resulted in a heterogeneous assemblage which was treated by subsequent workers as one genus (e.g. Boeckeler, 1870; Clarke, 1894, 1898, 1902; Hitchcock et al., 1969) or split into a number of smaller genera (e.g. Brown, 1810; Raynal 1973; Wilson, 1981; Goetghebeur, 1998).

Classification of genera into tribes in Cyperoideae has differed widely among authors, depending on which character(s) were emphasized. Therefore, there is a need to revise generic and tribal circumscriptions and especially incorporate new evidence from morphology and DNA sequence data.

\section{Taxonomic History of Tribe Cypereae}

Tribal concepts in Cyperoideae have varied over the years. A large number of legitimate tribal names have been published in Cyperoideae, including Cypereae, Scirpeae, Fuireneae, Ficinieae, Schoenoplecteae, Abildgaardieae, Lipocarpheae, and Eleocharideae (Goetghebeur, 1985). Cypereae and Scirpeae have been the most frequently used tribal names (e.g. Haines \& Lye, 1983; Bruhl, 1995; Goetghebeur, 1998). The main difference has traditionally been that Scirpeae have spirally arranged glumes whereas in Cypereae glumes are two-ranked (e.g. Lye, 1971). However, this tribal classification has resulted in genera such as Oxycaryum and Isolepis being classified in Scirpeae even though these genera show closer affinity to Cyperus, as pointed out by Raynal (1973).

Embryological data (e.g. Van der Veken, 1965; Haines \& Lye, 1971, 1976, 1983; Raynal, 1973, 1977; Wilson, 1981; Goetghebeur, 1996, 1998; Bruhl, 1995) have contributed significantly to generic and tribal circumscription in Cyperoideae. Heterogeneous Scirpus sensu lato has embryo types characteristic of Cyperus, Carex, Bulbostylis, Fimbristylis, Schoenus and Schoenoplectus, whereas Cyperus has mainly the Cyperus-type embryo. Based on the interpretation that several genera could have the same type of embryo but a single genus should have only a single type of embryo, Scirpus sensu lato was split into several genera. Currently (Geotghebeur, 1998), tribes in Cyperoideae are classified to include genera sharing a single embryo type. For example, Cypereae have the Cyperus-type embryo and the similar Ficinia-type, whereas Scirpeae sensu stricto have only the Fimbristylis-type embryo. 
Two recent classifications of Cyperoideae, based predominantly on morphological data, have differed in placement of genera in Cypereae. Goetghebeur (1998) classified all taxa characterised by Cyperus-type embryo in Cypereae, whereas Bruhl (1995) placed genera having spiral glume arrangement (i.e. Isolepis, Ficinia, Desmoschoenus, Scirpoides, Kyllingiella, Oxycaryum) in Scirpeae. Hellmuthia, bearing spirally arranged glumes but having an additional pair of scales in flowers subtended by the most proximal glumes, was placed in Scirpeae by Bruhl (1995) but in Chrysitricheae by Goetghebeur (1998). Bruhl (1995) did not recognise the tribes Eleocharideae and Fuireneae (sensu Goetghebeur, 1998), but included these taxa in Scirpeae.

\section{Phylogeny, Character Homology Assessment and Generic Circumscription}

\section{Phylogenetic Relationship Based on Molecular Data}

Over the last ten years, molecular systematic data have been used in the classification of ranks above family (e.g. APG, 2003) and in supraqeneric classification within Cyperaceae (Muasya et al., 1998, 2000a; Simpson et al., 2007). Studies on Cyperoideae have targeted phylogenetic relationships in Scirpeae (Muasya et al., 2000b, Dhooge et al., 2003) and Abildgaardieae (Ghamkhar et al., 2007), and focussed on genera Eleocharis (Roalson \& Friar, 2000; Yano et al., 2004), Isolepis (Muasya et al., 2001a), Cyperus sensu lato (Muasya et al., 2002) and Schoenoplectus (Yano \& Hoshino, 2005).

Total DNA was extracted from leaves or culms collected in the field or from herbarium specimens (Table 1). DNA extraction, amplification and sequencing were performed according to published procedures (e.g. Muasya et al., 2001a, 2002), and the resulting sequences aligned manually. We present and discuss here results of a maximum parsimony analysis of representatives of 18 of the 19 genera in Cypereae recognised by us; no material of the monotypic genus Ascopholis was available. The DNA data matrix ( $r b c L$ gene, $r p s 16$ intron, $t r n L$ intron and $t r n L-F$ intergenic spacer) comprises 3,721 characters among which 625 are potentially parsimony-informative. The matrix was analysed using the heuristic algorithm in PAUP* (Swofford, 2002), random addition for 10,000 replicates with tree-bisection-reconnection (TBR). Bootstrap analysis was performed for 1,000 replicates under maximum parsimony criterion (random taxon addition, twin replicates, TBR).

The strict consensus tree generated from the maximum parsimony analysis is presented in Fig. 1, with the bootstrap values for the various branches mapped. Cypereae are resolved into the Cyperus and Ficinia clades. The Ficinia clade comprises Scirpoides, Hellmuthia, Isolepis, Ficinia, Desmoschoenus and two Scirpus species ( $S$. falsus and S. ficinioides). The Cyperus clade has Cyperus sensu stricto as the core genus, in which the thirteen derived genera (Alinula, Androtrichum, Ascolepis, Courtoisina, Kyllinga, Kyllingiella, Lipocarpha, Oxycaryum, Pycreus, Queenslandiella, Remirea, Sphaerocyperus, and Volkiella) are embedded.

Assessment of Morphological Character Homology

Using the DNA phylogenetic framework (Fig. 1), we evaluate the homology of key morphological characters used in classification of the Cypereae. The morphological 
Table 1 List of Taxa Sampled with Vouchers and Genbank Accession Numbers

\begin{tabular}{|c|c|c|c|c|}
\hline \multirow[t]{2}{*}{ Taxon } & \multirow[t]{2}{*}{ Voucher } & \multicolumn{3}{|c|}{ GenBank accession numbers } \\
\hline & & $r b c L$ & rps16 & $\begin{array}{l}\text { trnL-F OR } \\
\text { intron/spacer }\end{array}$ \\
\hline \multicolumn{5}{|l|}{ Cyperoideae Suess. } \\
\hline \multicolumn{5}{|l|}{ Abildgaardieae Lye } \\
\hline $\begin{array}{l}\text { Abildgaardia ovata } \\
\text { (Burm. f.) Kral }\end{array}$ & $\begin{array}{l}\text { Kenya: Muasya et al. } 684 \\
(\mathrm{EA}, \mathrm{K})\end{array}$ & Y12985 & & AJ295754 \\
\hline $\begin{array}{l}\text { Fimbristylis dichotoma (L.) } \\
\text { Vahl }\end{array}$ & $\begin{array}{l}\text { Kenya: Muasya } 1006 \\
(\mathrm{EA}, \mathrm{K})\end{array}$ & Y13008 & & AJ295755 \\
\hline \multicolumn{5}{|l|}{ Cypereae Dumort. } \\
\hline $\begin{array}{l}\text { Alinula lipocarphoides } \\
\text { (Kük.) J. Raynal }\end{array}$ & Kenya: Muasya: 2592 (EA) & - & - & EF178608 \\
\hline $\begin{array}{l}\text { Alinula paradoxa Goetgh. \& } \\
\text { Vorster }\end{array}$ & $\begin{array}{l}\text { Tanzania: Faden et al. } \\
96 / 29(\mathrm{~K})\end{array}$ & AJ278290 & - & AJ295756 \\
\hline $\begin{array}{l}\text { Androtrichum giganteum } \\
\text { (Kunth) H. Pfeiff. }\end{array}$ & $\begin{array}{l}\text { Argentina: Tressens et al. } \\
4292(\mathrm{~K})\end{array}$ & EF178546 & & - \\
\hline $\begin{array}{l}\text { Androtrichum trigynum } \\
\text { (Spreng.) H. Pfeiff. }\end{array}$ & $\begin{array}{l}\text { Argentina: Goetghebeur } \\
4764 \text { (GENT) }\end{array}$ & EF178547 & & - \\
\hline $\begin{array}{l}\text { Ascolepis capensis (Kunth) } \\
\text { Ridl. }\end{array}$ & $\begin{array}{l}\text { Kenya: Muasya } 1009 \\
(\mathrm{EA}, \mathrm{K})\end{array}$ & Y13003 & AF449518 & AJ295757 \\
\hline Ascolepis protea Welw. & Congo: Fay $2700(\mathrm{~K})$ & Y13002 & - & - \\
\hline $\begin{array}{l}\text { Courtoisina assimilis } \\
\text { (Steud.) Maquet }\end{array}$ & $\begin{array}{l}\text { Tanzania: Faden et al. } \\
96 / 119(\mathrm{~K})\end{array}$ & AY40590 & AY449519 & AY040595 \\
\hline Cyperus compressus L. & Thailand: Muasya 1375 (K) & AF449506 & AF449521 & AF449555/- \\
\hline Cyperus cuspidatus Kunth & Thailand: Muasya $1374(\mathrm{~K})$ & AF449508 & AF449523 & $\begin{array}{l}\text { AF449557/ } \\
\text { AF449569 }\end{array}$ \\
\hline Cyperus involucratus Rottb. & $\begin{array}{l}\text { Madagascar: Kew Acc. } \\
6136603\end{array}$ & Y12967 & AF445920 & AJ295758 \\
\hline Cyperus laevigatus L. & Kenya: Muasya 1041 (EA) & Y13017 & AF449527 & AY040596 \\
\hline Cyperus longus L. & Europe: Chase $2276(\mathrm{~K})$ & Y13015 & AF449528 & AY040598 \\
\hline Cyperus papyrus L. & Chad: Hepper $4213(\mathrm{~K})$ & Y12966 & AF449531 & AJ295759 \\
\hline Cyperus pulchellus $\mathrm{R} . \mathrm{Br}$. & Thailand: Muasya 1377 (K) & AY40591 & - & AY040599 \\
\hline Cyperus pygmaeus Rottb. & Kenya: Muasya $1133(\mathrm{~K})$ & AJ404698 & AF449534 & AJ295760 \\
\hline $\begin{array}{l}\text { Desmoschoenus spiralis } \\
\text { Hook. f. }\end{array}$ & $\begin{array}{l}\text { New Zealand: Ford 44/94 } \\
\text { (NU) }\end{array}$ & AJ404701 & - & AJ295753 \\
\hline Ficinia bergiana Kunth & S. Africa: Muasya 2337 (BOL) & EF200588 & EF078974 & EF178593 \\
\hline Ficinia distans C. B. Clarke & S. Africa: Muasya 2283 (BOL) & EF178548 & & EF178594 \\
\hline $\begin{array}{l}\text { Ficinia esterhuyseniae } \\
\text { Muasya }\end{array}$ & S. Africa: Muasya 2312 (BOL) & EF178549 & EF078975 & EF178590 \\
\hline Ficinia gracilis Schrad. & $\begin{array}{l}\text { Tanzania: Faden et al. } \\
96 / 433(\mathrm{~K})\end{array}$ & EF178550 & & EF178534 \\
\hline $\begin{array}{l}\text { Ficinia nodosa (Rottb.) } \\
\text { Goetgh., Muasya \& D. A. } \\
\text { Simpson }\end{array}$ & Australia: Stind $21216(\mathrm{~K})$ & Y12984 & EF174386 & AJ295793 \\
\hline Ficinia rigida Levyns & S. Africa: Muasya $2319(\mathrm{~K})$ & EF178557 & EF174387 & EF178602 \\
\hline $\begin{array}{l}\text { Ficinia trichodes (Schrad.) } \\
\text { Benth. \& Hook. f. }\end{array}$ & S. Africa: Muasya $2328(\mathrm{~K})$ & EF178558 & EF174388 & EF178603 \\
\hline Ficinia radiata (L. f.) Kunth & S. Africa: Muasya $2310(\mathrm{~K})$ & EF200589 & EF078976 & - \\
\hline $\begin{array}{l}\text { Hellmuthia membranacea } \\
\text { (Thunb.) R. W. Haines \& } \\
\text { Lye }\end{array}$ & $\begin{array}{l}\text { S. Africa: Weerderman et al. } \\
269(\mathrm{~K}) \text {; Muasya } 1145(\mathrm{~K})\end{array}$ & Y13000 & EF174389 & AJ295815 \\
\hline $\begin{array}{l}\text { Isolepis cernua (Vahl) } \\
\text { Roem. \& Schult. var. } \\
\text { cernua }\end{array}$ & BRITAIN: Muasya 1058 (K) & Y13014 & AF449538 & AJ295775 \\
\hline Isolepis fluitans (L.) R. Br. & Kenya: Muasya 1057 (K) & Y12961 & EF174390 & AJ295780 \\
\hline
\end{tabular}


Table 1 (continued)

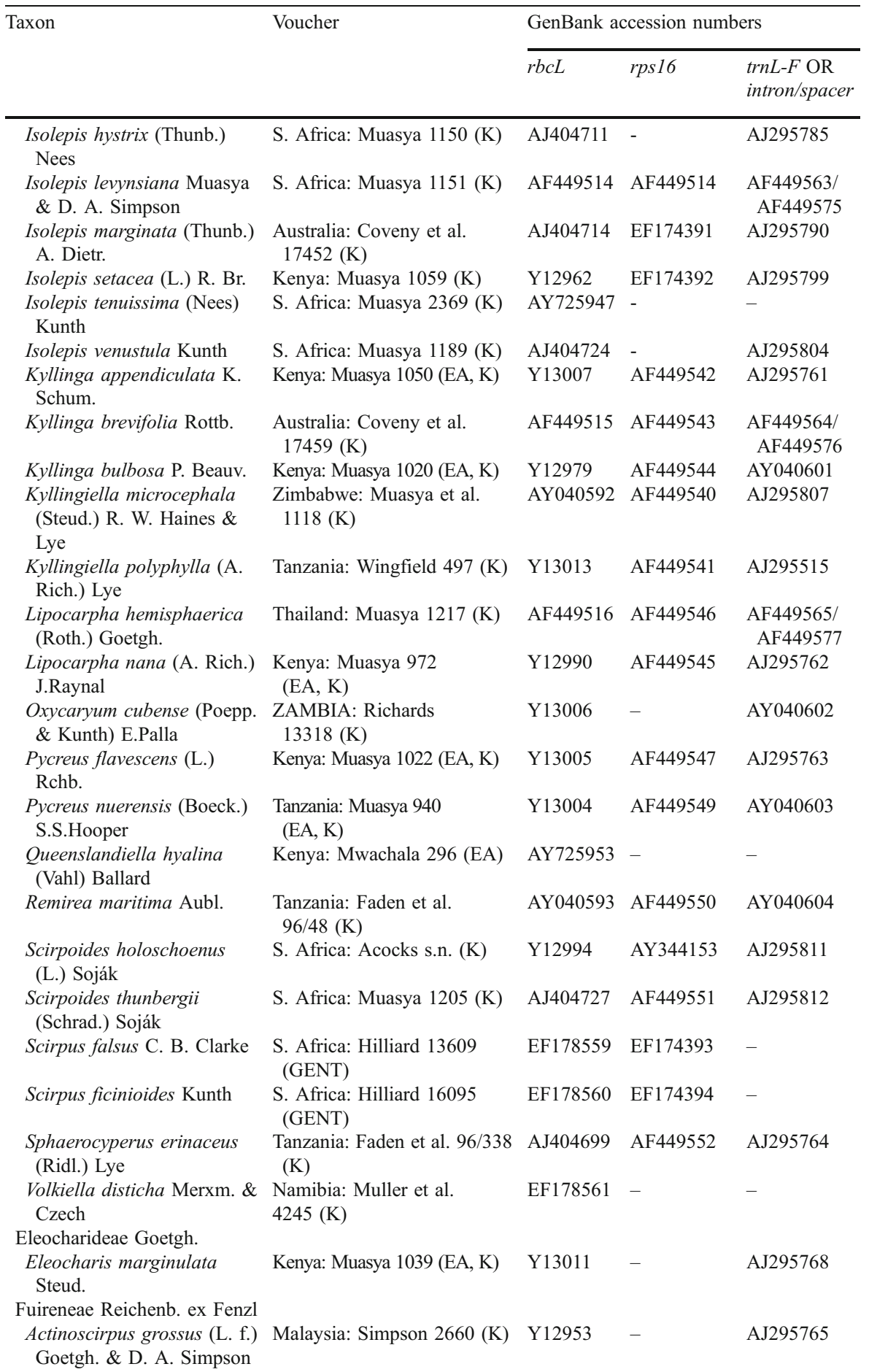


Table 1 (continued)

\begin{tabular}{|c|c|c|c|c|}
\hline \multirow[t]{2}{*}{ Taxon } & \multirow[t]{2}{*}{ Voucher } & \multicolumn{3}{|c|}{ GenBank accession numbers } \\
\hline & & $r b c L$ & rps16 & $\begin{array}{l}\text { trnL-F OR } \\
\text { intron/spacer }\end{array}$ \\
\hline $\begin{array}{l}\text { Bolboschoenus maritimus } \\
\text { (L.) Palla }\end{array}$ & Botswana: Smith $2452(\mathrm{~K})$ & Y12996 & - & AJ295767 \\
\hline $\begin{array}{l}\text { Bolboschoenus nobilis } \\
\text { (Ridl.) Goetgh. \& D. A. } \\
\text { Simpson }\end{array}$ & S. Africa: Leistner $144(\mathrm{~K})$ & Y12995 & - & - \\
\hline Fuirena sp. & $\begin{array}{l}\text { Brazil: Thomas et al. } 10404 \\
\text { (NY) }\end{array}$ & Y12970 & - & - \\
\hline $\begin{array}{l}\text { Isolepis humillima (Benth.) } \\
\text { K. L. Wilson }\end{array}$ & $\begin{array}{l}\text { Australia: Thomas et al. } 622 \\
\text { (BRI) }\end{array}$ & AJ404728 & AF449539 & AJ295784 \\
\hline $\begin{array}{l}\text { Schoenoplectiella articulata } \\
\text { (L.) Lye }\end{array}$ & $\begin{array}{l}\text { Tanzania: Muasya } 947 \\
(\mathrm{EA}, \mathrm{K})\end{array}$ & Y12987 & - & - \\
\hline $\begin{array}{l}\text { Schoenoplectus corymbosus } \\
\text { (Roth ex Roem. \& Schult.) } \\
\text { J. Raynal }\end{array}$ & Kenya: Muasya 1004 (EA) & EF178570 & - & EF178607 \\
\hline $\begin{array}{l}\text { Schoenoplectus lacustris (L.) } \\
\text { Palla }\end{array}$ & Britain: Muasya $1043(\mathrm{~K})$ & Y12943 & AF449554 & AJ295809 \\
\hline $\begin{array}{l}\text { Schoenoplectus litoralis } \\
\text { (Schrad.) Palla }\end{array}$ & Hong Kong: Shaw $883(\mathrm{~K})$ & EF178571 & - & - \\
\hline \multicolumn{5}{|l|}{ Scirpeae Kunth ex Dumort. } \\
\hline Eriophorum vaginatum $\mathrm{L}$. & Poland: Beyer et al. $2(\mathrm{~K})$ & Y12951 & AF449553 & AJ295769 \\
\hline $\begin{array}{l}\text { Eriophorum viridicarinatum } \\
\text { (Engl.) Fern. }\end{array}$ & USA: Boufford 23053 (WS) & $\mathrm{U} 49230$ & - & - \\
\hline $\begin{array}{l}\text { Scirpus ancistrochaetus } \\
\text { Schuyler }\end{array}$ & USA: Nacsi 7544 (DOV) & EF178578 & EF174395 & - \\
\hline Scirpus sylvaticus $\mathrm{L}$. & HBUG/86-0541 (GENT) & EF178586 & EF174396 & - \\
\hline \multicolumn{5}{|l|}{ Mapanioideae C. B. Clarke } \\
\hline $\begin{array}{l}\text { Hypolytreae Presl ex Fenzl } \\
\text { Hypolytrum nemorum (Vahl) } \\
\text { Spreng. }\end{array}$ & Malaysia: Simpson 1379 (K) & Y12958 & AY344142 & AJ295816 \\
\hline $\begin{array}{l}\text { Mapania cuspidata (Miq.) } \\
\text { Uittien }\end{array}$ & Brunei: Marsh $4(\mathrm{~K})$ & Y12955 & DQ058318 & AJ295817 \\
\hline
\end{tabular}

Classification following interpretation of current data and Goetghebeur (1998)

characters are manually plotted on the DNA topology, majority of characters can be unambiguously reconstructed on the phylogeny. Ascopholis, a monotypic genus restricted to India (Goetghebeur, 1998), has not been included in this study due to unavailability of material. Generic status of Ascopholis is not accepted by all, and it has been suggested to be conspecific to the widespread Cyperus mollipes (C. B. Clarke) K. Schum (Govaerts et al., 2007).

\section{Mature Embryo Morphology}

Cypereae are characterised by the presence of a Cyperus-type embryo (Van der Veken, 1965; Haines \& Lye, 1971, 1976; Raynal 1973; Wilson, 1981; Goetghebeur, 1985). In the Ficinia clade, species of Ficinia have a Ficinia-type embryo which is similar to Cyperus-type, but Isolepis, Hellmuthia and Scirpoides have a typical Cyperus-type embryo (Van der Veken, 1965; Haines \& Lye, 1971). The embryo type 
Fig. 1 Maximum parsimony strict consensus tree of Cypereae based on heuristic analysis of plastid DNA sequence data. Cyperus and Ficinia clades are marked by black and grey bars respectively. Bootstrap support values shown as *for $50-74 \%$, ** for $75-89 \%$ and *** for $90-100 \%$

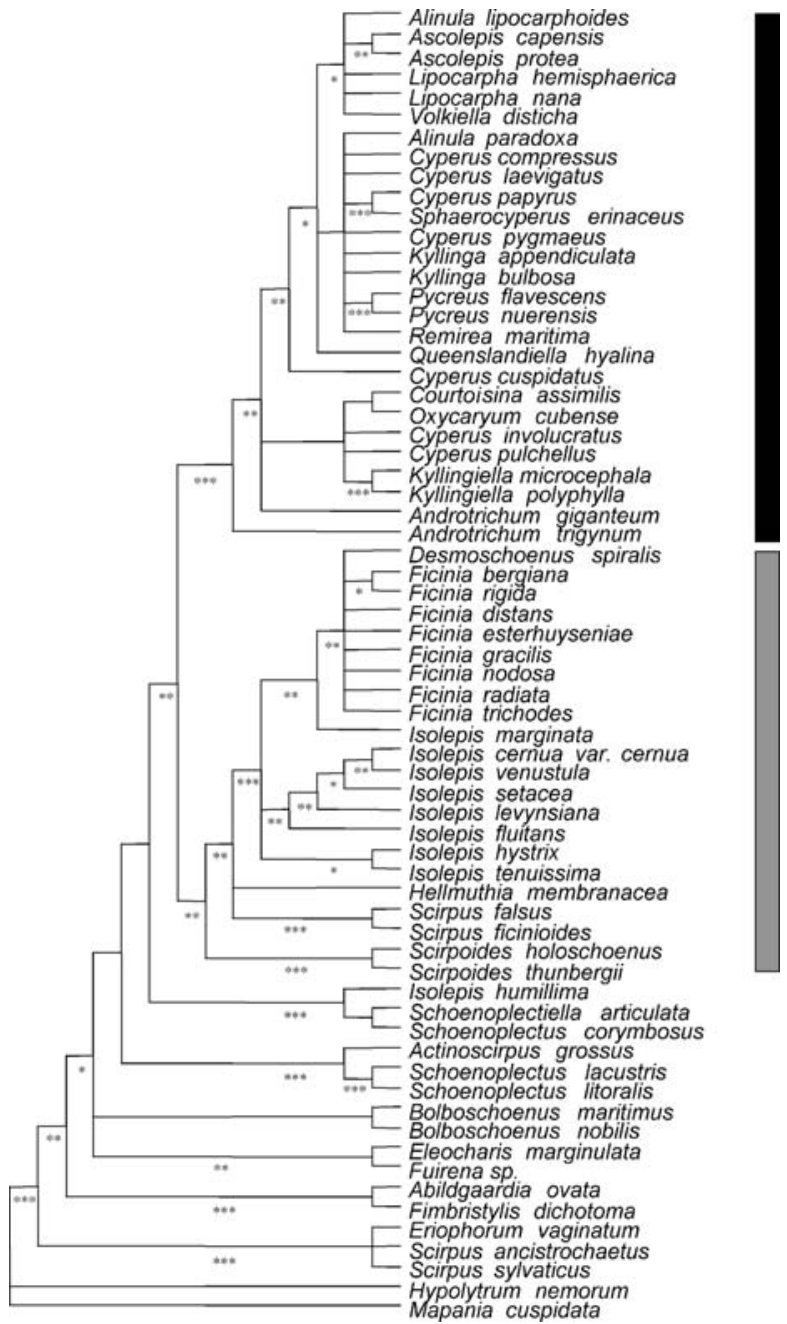

in Scirpus falsus and S. ficinioides has not been studied, mainly because mature nutlets were not available.

Concepts of mature embryo morphological states are subject to individual interpretation of homology, and it may be difficult to distinguish similar embryo types in some cases. For example, Isolepis humillima, placed in Isolepis due to the presence of spiral glume arrangement, has been interpreted as having an embryo similar to Scirpoides (Wilson, 1981). The phylogenetic position of this taxon in molecular analyses is within Schoenoplectus subgen. Actaeogeton, a group possessing a Schoenoplectus-type embryo. The mature embryo in Cypereae is less complex when compared to state is the sister tribe Fuireneae (Schoenoplectus type), hence our study does not support Juguet's contention (as reported in Raynal, 1973) that the embryogeny of Cypereae is very evolved compared to the rest of the family. 
Table 2 Summary of Some of the Diagnostic Characters of the Genera in Cypereae

\begin{tabular}{|c|c|c|c|c|c|c|}
\hline $\begin{array}{l}\text { Genus (total/ } \\
\text { studied species) }\end{array}$ & Habit & $\begin{array}{l}\text { Floret } \\
\text { no. }\end{array}$ & $\begin{array}{l}\text { Glume } \\
\text { arrangement }\end{array}$ & $\begin{array}{l}\text { Dispersal } \\
\text { unit }\end{array}$ & $\begin{array}{l}\text { Nutlet } \\
\text { orientation }\end{array}$ & $\begin{array}{l}\text { Photosynthetic } \\
\text { type }\end{array}$ \\
\hline Alinula $(4 / 2)$ & Annual & One & Distichous & Nutlet & Dorsiventral & $\mathrm{C}_{4}$ \\
\hline Androtrichum (2/2) & Perennial & Many & Distichous & $\begin{array}{l}\text { Nutlet \& } \\
\text { filaments }\end{array}$ & Dorsiventral & $\mathrm{C}_{3}$ \\
\hline Ascolepis $(20 / 2)$ & $\begin{array}{l}\text { Annual/ } \\
\text { perennial }\end{array}$ & One & Distichous & $\begin{array}{l}\text { Spikelet/ } \\
\text { nutlet }\end{array}$ & Dorsiventral & $\mathrm{C}_{4}$ \\
\hline Ascopholis (1/0) & Perennial & One & Distichous & Spikelet & Dorsiventral & $\mathrm{C}_{4}$ \\
\hline Courtoisina $(2 / 1)$ & Annual & Many & Distichous & Spikelet & Dorsiventral & $\mathrm{C}_{3}$ \\
\hline Cyperus (550/7) & $\begin{array}{l}\text { Annual/ } \\
\text { perennial }\end{array}$ & 1-Many & $\begin{array}{l}\text { Distichous/ } \\
\text { spiral }\end{array}$ & $\begin{array}{l}\text { Spikelet/ } \\
\text { nutlet }\end{array}$ & Dorsiventral & $\mathrm{C}_{3} \& \mathrm{C}_{4}$ \\
\hline Desmoschoenus (1/1) & Perennial & Many & Spiral & Nutlet & Dorsiventral & $\mathrm{C}_{3}$ \\
\hline Ficinia $(60 / 8)$ & Perennial & Many & $\begin{array}{l}\text { Distichous/ } \\
\text { spiral }\end{array}$ & Nutlet & Dorsiventral & $\mathrm{C}_{3}$ \\
\hline Hellmuthia (1/1) & Perennial & Many & Spiral & Nutlet & Dorsiventral & $\mathrm{C}_{3}$ \\
\hline Isolepis $(70 / 9)$ & $\begin{array}{l}\text { Annual } \\
\text { (perennial) }\end{array}$ & Many & $\begin{array}{l}\text { Distichous/ } \\
\text { spiral }\end{array}$ & Nutlet & Dorsiventral & $\mathrm{C}_{3}$ \\
\hline Kyllinga $(60 / 2)$ & $\begin{array}{r}\text { Perennial } \\
\text { (annual) }\end{array}$ & Many & Distichous & Spikelet & Lateral & $\mathrm{C}_{4}$ \\
\hline Kyllingiella $(4 / 2)$ & Perennial & Many & Spiral & Nutlet & Dorsiventral & $\mathrm{C}_{3}$ \\
\hline Lipocarpha $(35 / 2)$ & $\begin{array}{l}\text { Annual/ } \\
\text { perennial }\end{array}$ & One & Distichous & Spikelet & Dorsiventral & $\mathrm{C}_{4}$ \\
\hline Oxycaryum $(1 / 1)$ & $\begin{array}{l}\text { Annual } \\
\text { (perennial) }\end{array}$ & Many & Spiral & Nutlet & Dorsiventral & $\mathrm{C}_{3}$ \\
\hline Pycreus (100/2) & $\begin{array}{l}\text { Annual/ } \\
\text { perennial }\end{array}$ & Many & Distichous & Nutlet & Lateral & $\mathrm{C}_{4}$ \\
\hline Queenslandiella $(1 / 1)$ & Annual & Many & Distichous & Spikelet & Lateral & $\mathrm{C}_{4}$ \\
\hline Remirea $(1 / 1)$ & Perennial & One & Distichous & Spikelet & Dorsiventral & $\mathrm{C}_{4}$ \\
\hline Scirpoides $(5 / 2)$ & Perennial & Many & Spiral & Nutlet & Dorsiventral & $\mathrm{C}_{3}$ \\
\hline $\begin{array}{r}\text { Scirpus spp. }(3 / 2 ; \\
\text { Southern Africa) }\end{array}$ & Perennial & Many & Spiral & Nutlet & Dorsiventral & $?$ \\
\hline Sphaerocyperus (1/1) & Perennial & One & Distichous & Spikelet & Dorsiventral & $\mathrm{C}_{4}$ \\
\hline Volkiella $(1 / 1)$ & Annual & One & Distichous & Spikelet & Dorsiventral & $\mathrm{C} 4$ \\
\hline
\end{tabular}

Classification following interpretation of current data and Goetghebeur (1998).

\section{Annual Versus Perennial Life Form}

Annual and perennial growth forms are observed among members of tribe Cypereae (Haines \& Lye, 1983; Goetghebeur, 1998; Table 2). In the Ficinia clade, an annual life form has evolved only in Isolepis (which also has some perennial species) whereas all other taxa are perennial. In the Cyperus clade, an annual life form is exclusively found in Courtoisina, Queenslandiella and Alinula; a predominantly perennial life form is observed in Oxycaryum, Kyllingiella, Remirea, Sphaerocyperus, Kyllinga and Ascolepis); while both annual and perennial life forms are recorded in Cyperus sensu stricto, Pycreus and Lipocarpha.

\section{Glume Arrangement}

Spiral glume arrangement is a plesiomorphic state in Cyperoideae (Muasya et al., 2001b). In Cypereae (Table 2), the Ficinia clade has predominantly a spiral glume 
arrangement, except in few species of Ficinia (e.g. F. distans and F. angustifolia) and Isolepis (I. levynsiana and I. venustula). In the Cyperus clade, distichous glume arrangement is usual especially in Androtrichum, Cyperus sensu stricto, Courtoisina, Pycreus, Kyllinga, Queenslandiella, Sphaerocyperus, Remirea, and Volkiella. Oxycaryum, Kyllingiella and Alinula have a spiral glume arrangement, while the spikelet is too reduced in Ascolepis and Lipocarpha for interpretation of glume arrangement (Goetghebeur, 1998). Distichous glume arrangement has evolved more than once in Cypereae, occurring in both the Ficinia and Cyperus clades, and is therefore not unique in Cyperus sensu stricto. The unreliability of distichous arrangement as a diagnostic character has been previously shown (e.g. Raynal, 1973), and evident from our study where taxa with the Cyperus-like distichous glume arrangement (e.g. Isolepis levynsiana) are resolved in the Ficinia clade.

\section{Hypogynous Scales}

Hypogynous scales, a character considered plesiomorphic in Cyperoideae, are found in Scirpeae, Fuireneae, Eleocharideae, Dulichieae, and Schoeneae but are absent from Abildgaardieae and Cypereae (Goetghebeur, 1998). Scirpus falsus and $S$. ficinioides, resolved in Cypereae in molecular phylogenetic analyses (Fig. 1), have bristle-like perianth segments. Similar perianth segments, some well developed and others rudimentary, have been observed in Ficinia material (Muasya et al., unpublished results).

Some florets in Hellmuthia have two scales, which have been suggested to be homologous to scales in Mapanioideae (Haines \& Lye, 1976; Goetghebeur, 1998). Recent floral ontogenetic studies (Vrijdaghs et al., 2006) have revealed an adaxially situated third scale in some proximal flowers in spikelets of Hellmuthia, and these are interpreted to be perianth segments and not glumes of reduced florets as in Mapanioideae. Hellmuthia is resolved in the DNA phylogeny among the Ficinia clade and closely related to Scirpus falsus and S. ficinioides.

\section{Gynophores}

The gynophore in Cypereae, formed by the development of the hypogynous stalk, is characterised by a lobed cup that envelops the basal part of the nutlet (Vrijdaghs et al., 2005). This structure is absent from the rest of Cyperoideae except for Ficinia, in which variation is observed in size and shape of the gynophore. However, some Ficinia species lack a gynophore, while on the other hand some Isolepis species (e.g. I. marginata) have a rudimentary gynophore (Clarke, 1898; Levyns, 1950; Muasya et al., 2000c, 2001a). A gynophore is present in Alinula lipocarphoides, a taxon previously described in Ficinia and later transferred to Alinula (Kükenthal, 1936; Raynal, 1977), here resolved in the Cyperus clade as sister to Lipocarpha.

\section{Kranz Anatomy}

As in most angiosperms families, the plesiomorphic photosynthetic system in most of Cyperaceae is $\mathrm{C}_{3}$ type. Multiple origins of Kranz anatomy are recorded in several lineages including Rhynchospora, Eleocharis, Fimbristylis and Cyperus (Raynal, 
1973; Estelita, 1993; Goetghebeur, 1998; Soros \& Bruhl, 2000; Muasya et al., 2002; Bruhl \& Wilson, 2007). Among Cypereae, Kranz anatomy has evolved once among Cyperus clade and is recorded in Fig. 1 between Cyperus cuspidatus to Alinula lipocarphoides. Bruhl \& Wilson (2007) erroneously reported Volkiella to be C3, while in the supporting references they show isotopic carbon reading $(-13.6)$ which is typical for $\mathrm{C}_{4}$.

Samples of Alinula paradoxa and Lipocarpha rehmannii, reported to be $\mathrm{C}_{3}$ (Stock et al., 2004), might have been based on wrongly identified material, especially since there are four other records as $\mathrm{C}_{4}$ for L. rehmannii (Bruhl and Wilson, 2007), and recent carbon isotope studies have confirmed other samples of these taxa to be $\mathrm{C}_{4}$ (Muasya, unpublished results).

\section{Inflorescence Morphology}

Inflorescence morphology varies greatly in Cypereae. The basic inflorescence has spikelets in a panicle (Raynal, 1971), which is often modified into an anthela or contracted into a capitate head, spike or reduced to a single spikelet (Goetghebeur, 1998). In Cyperus, $\mathrm{C}_{3}$ taxa tend to have the spikelets arranged in digitate clusters, which is one of the few morphological characters to distinguish the $\mathrm{C}_{3}$ and $\mathrm{C} 4$ taxa (which are usually spicately arranged), apart from those species that have the inflorescence reduced to a head (Goetghebeur, 1998). Kükenthal (1935-1936) used this (only partly correctly) to subdivide his subgenus 'Eu-cyperus', while Raynal (1973) also noted this (as not being a simple dividing character) particularly in discussing the origins of the 'Mariscus' group of species.

Spikelets in a majority of Cypereae have many flowers. Several genera (e.g. Lipocarpha, Ascolepis, Alinula) have pseudo-spikelets, in which spikelets are reduced to single flowers (glumes lost) arranged in cones, each single-flower spikelet subtended by a glume-like bract. The resulting cone resembles a spikelet (Haines \& Lye, 1983; Goetghebeur \& Vorster, 1988) hence the use of the term 'pseudo-spikelet'.

\section{Elongation of Filaments}

Stamen filaments in most members of Cyperoideae are nearly as long as the glumes and inconspicuous after anthesis. Androtrichum trigynum and A. giganteum have filaments strongly elongating after anthesis, giving the inflorescence a cotton-like look. Such elongation of filaments is not observed in any other species in Cyperoideae.

\section{Dispersal unit}

Nutlets (also called achenes by some authors, e.g. Goetghebeur, 1998) in members of Cypereae are dispersed singly or together with elongated filaments, one to a few glumes, or parts of the spikelet axis, or even as complete spikelets (Kükenthal, 1935-1936; Raynal, 1973; Haines \& Lye, 1983; Goetghebeur, 1998; Table 2). Courtoisina, Queenslandiella, Kyllinga, Remirea, Sphaerocyperus, Lipocarpha, and Ascolepis have spikelets dispersing as intact units, whereas all taxa in the Ficinia 
clade, Kyllingiella, Pycreus, Oxycaryum, and Remirea have nutlets dispersed singly. Cyperus has nutlets dispersed either singly or as whole spikelets or variants thereof (notably in Cyperus odoratus).

\section{Nutlet Orientation}

Two kinds of nutlet orientation are observed in Cypereae (Table 2). Dorsiventral nutlet orientation is the most common and plesiomorphic state (Kükenthal, 19351936; Goetghebeur, 1998; Muasya et al., 2001b). Within Cypereae and Cyperaceae, species with distigmatic styles and dorsiventrally compressed nutlets are observed. Only the genera Kyllinga, Pycreus, and Queenslandiella have lateral nutlet orientation with distigmatic styles and laterally compressed nutlets.

\section{Generic Circumscription}

Cypereae are defined here as including all taxa sharing the Cyperus-type of embryo. We expand the tribal circumscription to include characters states such as the occasional presence of floral scales and bristle-like perianth segments, observed in the Ficinia clade.

\section{The Ficinia Clade}

Taxa in this clade have a predominantly spiral glume arrangement, but note the presence of distichous glume arrangement in Ficinia and Isolepis. All the genera share ficinioid morphology, e.g. tufted perennials, spiral glume arrangement, and have a center of diversity in the Cape floristic region of South Africa (Goetghebeur, 1998; Archer, 1998; Muasya \& Simpson, 2002; Muasya, 2005). The individual genera are diagnosed by a combination of several characters (Table 2), the most notable being the presence of a gynophore and ligule in Ficinia (including Desmoschoenus), presence of two or three scales in the lower florets in Hellmuthia, and perennial growth form and spiral glume arrangement in Scirpoides, whereas Isolepis includes predominantly annual species with a spiral glume arrangement. Two annual species (Isolepis leucoloma and I. levynsiana) with distichous glumes previously described in Cyperus have been transferred to Isolepis, based on morphological and molecular data (Archer, 1998; Muasya et al., 2006, 2007).

There is overlap in generic limits between Isolepis and Ficinia as presently recognised, whereas Desmoschoenus is embedded in Ficinia (Fig. 1). An annual species with rudimentary gynophore described as Isolepis (I. marginata) is resolved in DNA analysis as more closely related to Ficinia. Desmoschoenus and Sickmannia (Ficinia radiata), taxa with a gynophore but with additional unique features, have been recognised as distinct from Ficinia. Phylogenetic results presented here (Fig. 1) show that these taxa are embedded in Ficinia, and should be recognized as members of Ficinia. Sickmannia has already been recognised as Ficinia (F. radiata) in recent treatments (Goetghebeur, 1998; Archer, 2000), whereas Desmoschoenus spiralis, a New Zealand endemic growing in the same coastal habitat as Ficinia nodosa, has no name in Ficinia. More studies are in progress to resolve relationships in the Ficinia clade. 
Two of the Scirpus species, S. falsus and S. ficinioides from southern Africa, have the gross morphology of the Ficinia clade, including perennial habit, scapose culms, pseudolateral inflorescences, and spiral glumes. Presence of perianth segments has been used to include these taxa in Scirpus (e.g. Kunth, 1837; Clarke, 1898; GordonGray, 1995) even though typical Scirpus has paniculate inflorescences and nodded culms. So far no embryo studies have been done on these taxa, and attempts to locate appropriate material have not been successful as the taxa rarely produce mature nutlets. Phylogenetic studies resolve these taxa as sister to Hellmuthia (Fig. 1), a pattern that suggests evolution from a southern African ancestor, unlike Scirpus, which is Holarctic. A new genus should be erected to include these two taxa, and more studies are in progress to formalise the recognition of this genus.

\section{The Cyperus Clade}

Genera in the Cyperus clade are circumscribed by a combination of morphological characters including spikelet morphology, unit of dispersal, and nutlet orientation (Table 2). Although these genera can be grouped into $\mathrm{C}_{3}$ and $\mathrm{C}_{4}$ anatomical types, there are few observable gross morphological characters to separate the species of Cyperus sensu stricto with the two kinds of anatomy.

Among $\mathrm{C}_{3}$ genera, Androtrichum is diagnosed by the presence of elongated stamen filaments that are persistent and dispersed with the nutlets. However, the two taxa, A. giganteum and A. trigynum, are not sister (Fig. 1) and their shared character state, presence of elongated filaments, may be a parallel adaptation to dispersal in swampy coastal dunes. Kyllingiella and Oxycaryum, previously classified in Scirpeae (e.g. Bruhl, 1995), have a spiral glume arrangement unlike $\mathrm{C}_{3}$ species of Cyperus sensu stricto, which have a distichous glume arrangement (Lye, 1971; Haines \& Lye, 1978). Courtoisina has similar morphology to $\mathrm{C}_{3}$ species of Cyperus, but the whole spikelet is dispersed intact.

The $\mathrm{C}_{4}$ genera include a number that are monotypic or with few species (i.e. Queenslandiella, Sphaerocyperus, Remirea, Volkiella, and Alinula), which are separated from the larger genera by a combination of characters. Among the clearly recognizable larger genera are Kyllinga, and Pycreus (together with monotypic Queenslandiella), which have laterally flattened nutlets. Alinula, Volkiella, Ascolepis, and Lipocarpha have highly reduced spikelets. The $\mathrm{C}_{4}$ species of Cyperus sensu stricto have spikelets comprising more than one floret and dorsiventrally compressed nutlets.

There are differences in opinion on whether to recognise Cyperus sensu lato, in a very broad sense with a number of subgenera (e.g. subgenus Kyllinga, and $\mathrm{C}_{3}$ and $\mathrm{C}_{4}$ species of Cyperus sensu stricto in different subgenera; e.g. Kükenthal, 19351936), or in a narrow sense with various segregate genera (with Cyperus sensu stricto including $\mathrm{C}_{3}$ and $\mathrm{C}_{4}$ species; e.g. Goetghebeur, 1998). Our results show Cyperus sensu stricto to be polyphyletic, and merging all the segregate taxa into broadly circumscribed Cyperus sensu lato and recognizing various segregates as subgenera would make a monophyletic entity. However, this option is not favored because it would result in a big genus (c. 900 species) and reduce taxonomic clarity. Other partial merging of the taxa into Cyperus, recognizing Oxycaryum, Kyllingiella, Sphaerocyperus, Remirea, Lipocarpha, and Ascolepis as distinct, but treating 
Courtoisina, Kyllinga, Pycreus, Queenslandiella, and Alinula as subgenera of Cyperus (e.g. Haines \& Lye, 1983; Lye, 1997) is not supported by this study.

We follow Goetghebeur (1998) in recognizing Cyperus sensu stricto and recognizing the segregate taxa at generic rank (Table 2) pending more intensive phylogenetic studies to get a full resolution of their relationships.

\section{Future Research}

Molecular phylogenetic studies have focused more attention on the Ficinia clade (38\% sampling) and less on the Cyperus clade (5\% sampling), yet Cyperus clade exhibits wide morphological variation. With more intensive molecular phylogenetic studies and more extensive sampling to include the complete diversity of growth form and morphological types, we expect a better understanding of character homology, which will allow better-informed decisions about generic limits.

Acknowledgements AMM acknowledges a visiting postdoctoral fellowship from the Belgian Fund for Scientific Research-Flanders (FWO-Vlaanderen, G.0104.01N) and a grant from the K.U. Leuven (grant F/ 02/052) during the period this paper was prepared.

Open Access This article is distributed under the terms of the Creative Commons Attribution Noncommercial License which permits any noncommercial use, distribution, and reproduction in any medium, provided the original author(s) and source are credited.

\section{Literature Cited}

APG. 2003. An update of the Angiosperm Phylogeny Group classification for the orders and families of flowering plants: APG II. Bot. J. Linn. Soc. 141: 399-436.

Archer, C. 1998. A new combination in Isolepis. Bothalia 28: 41-42. 2000. Cyperaceae. In: Goldblatt, P. \& Manning, J. eds., Cape Plants. A Conspectus of the Cape Flora of South Africa. Strelitzia 9: 81-92.

Boeckeler, O. 1870. Die Cyperaceen des Königlichen Herbariums zu Berlin. Linnaea 36: 271-768.

Brown, R. 1810. Prodomus florae Novae Hollandiae et insulae Van-Diemen vol. 1. London: Johnson.

Bruhl, J. J. 1995. Sedge genera of the world: relationships and a new classification of the Cyperaceae. Austral. Syst. Bot. 8: 125-305.

\& K. L. Wilson. 2007. Towards a comprehensive survey of $\mathrm{C}_{3}$ and $\mathrm{C}_{4}$ photosynthetic pathways in Cyperaceae. Aliso 23: 99-148. In J. T. Columbus, E. A. Friar, J. M. Porter, L. M. Prince \& M. G. Simpson, (eds.), Monocots: comparative biology and evolution, RSABG, California.

Clarke, C. B. 1894. Cyperaceae. In: Hooker, J. D. The Flora of British India 6: 585-748. 1898. Cyperaceae. In: Thiselton-Dyer, W.T. ed., Flora Capensis 7: 235-260. 1902. Cyperaceae. In: Thiselton-Dyer, W.T. ed., Flora of tropical Africa 8: 385-524.

Dhooge, S., P. Goetghebeur \& A. M. Muasya. 2003. Zameioscirpus, a new genus of Cyperaceae from South America. P1. Syst. Evol. 243(1-2): 73-84.

Estelita, M. E. M. 1993. Remirea Aubl. (Cyperaceae), a new Kranz genus. Revista Brasil. Bot. 16: 137141.

Ghamkhar, K., A. D. Marchant, K. L. Wilson \& J. J. Bruhl. 2007. Phylogeny of Abildgaardieae (Cyperaceae) inferred from ITS and trnL-F data. Aliso 23: 149-164. In J. T. Columbus, E. A. Friar, J. M. Porter, L. M. Prince \& M. G. Simpson, (eds.), Monocots: comparative biology and evolution, RSABG, California.

Goetghebeur, P. 1985. Studies in Cyperaceae 6. Nomenclature of the suprageneric taxa in the Cyperaceae. Taxon 34: 617-632.

-1996. Genera Cyperacearum. Dr. Sci. thesis, State University, Ghent 
1998. Cyperaceae. In: K. Kubitzki (ed.), The families and genera of vascular plants 4: 164. Springer, Berlin.

\& P. Vorster. 1988. Studies in Cyperaceae 7. The genus Alinula J. Raynal: a reappraisal. Bull. Jard. Bot. Nation. Belg. 58: 457-465.

Gordon-Gray, K. D. 1995. Cyperaceae in Natal. National Botanical Inst., Pretoria, South Africa.

Govaerts, R., D. A. Simpson, P. Goetghebeur, K. Wilson, T. Egorova \& J. Bruhl. 2007. World Checklist of Cyperaceae. The Board of Trustees of the Royal Botanic Gardens, Kew. Published on the Internet; http://www.kew.org/wcsp/monocots/ accessed 3 Nov. 2008.

Haines, R. W. \& K. A. Lye. 1971. Studies in African Cyperaceae 4. Lipocarpha R.Br., Hemicarpha Nees, and Isolepis R. Br. Bot. Notiser 124: 473-482.

\& 1 1976. Studies in African Cyperaceae 14. The genus Hellmuthia Steud. Bot. Notiser 129: 61-67.

\& 1 1978. Studies in African Cyperaceae 17. Kyllingiella R. Haines \& K. Lye, gen. nov. Bot. Notiser 131: 175-177.

\& 1 . 1983. The sedges and rushes of East Africa. East African Natural History Society, Nairobi.

Hitchcock, C. L., A. Cronquist \& M. Ownbey. 1969. Vascular plants of the Pacific Northwest. 1. Seattle \& London.

Kükenthal, G. 1935-1936. Cyperaceae-Scirpoideae-Cypereae. In A. Engler (ed.), Das Pflanzenreich, IV, 20 (101). Leipzig.

Kunth, C. S. 1837. Enumeratio Plantarum 2: 172. Stutgardiae \& Tubingae.

Levyns, M. R. 1950. Cyperaceae. In: Adamson, R. S. \& T. M. Salter, eds, Flora of the Cape Peninsula: 109-118.

Linnaeus, C. 1753. Species Plantarum, vol 1. Holmiae.

Lye, K. A. 1971. Studies in African Cyperaceae 2. The genus Oxycaryum Nees. Bot. Notiser 124: 280286.

- 1997. Cyperaceae. In: Edwards, S., S. Demissew \& I. Hedberg, eds., Flora of Ethiopia and Eritrea, vol. 6: 391-511.

Muasya, A. M. 2005. Ficinia anysbergensis and F. esterhuyseniae (Cyperaceae), two new species from the Cape Floristic Region of South Africa. S. Afr. J. Bot. 71: 197-200.

\& D. A. Simpson. 2002. A monograph of the genus Isolepis R.Br. (Cyperaceae). Kew Bull. 57: 257-362.

$\longrightarrow$ - $\longrightarrow$ M. W. Chase. 2001b. Generic relationships and character evolution in Cyperus sensu lato (Cyperaceae). Syst. Geogr. P1. 71: 539-544.

$\longrightarrow,-$ 2002. Phylogenetic relationships in Cyperus sensu lato (Cyperaceae) inferred from plastid DNA sequence data. Bot. J. Linn. Soc. 138: 145-153.

$\longrightarrow, \longrightarrow$ \& P. Goetghebeur. 2000c. New combinations in Trichophorum, Scirpoides and Ficinia (Cyperaceae). Novon 10: 132-133.

$\longrightarrow-1-$ \& E. Smets. 2006. Isolepis tenella, a new combination in Cyperaceae. Novon 16: 89-90. Novon 17: 59. $\boldsymbol{\&} \longrightarrow$. 2007. Isolepis levynsiana, a new name for Cyperus tenellus (Cyperaceae). Cyperaceae using rbcL DNA sequences. P1. Syst. Evol. 211: 257-271.

$\longrightarrow,-,-$ 2000b. Phylogenetic relationships within the heterogeneous Scirpus sensu lato. (Cyperaceae) inferred from $r b c L$ and $t r n L-F$ sequence data. In K. L. Wilson \& D. A. Morrison (eds.), Monocots: Systematics and Evolution, 610-614. CSIRO, Melbourne.

$\longrightarrow,-1$. 2001a. A phylogeny of Isolepis (Cyperaceae) inferred using plastid $r b c L$ and $\operatorname{trn} L-F$ sequence data. Syst. Bot. 26: 342-353.

—, J. J. Bruhl, D. A. Simpson, A. Culham \& M. W. Chase. 2000a. Suprageneric phylogeny of Cyperaceae: a combined analysis, pp. 593-601. In K. L. Wilson \& D. A. Morrison, (eds.), Monocots: systematics and evolution, CSIRO Publishing, Melbourne, Victoria, Australia.

Raynal, J. 1971. Quelques notes morphologigues sur les cyperacées. Mitt. Bot. Staatssamml. Münch. 10: 589-603.

- 1973. Notes Cypérologiques: 19. Contribution à la classification de la sous-famille des Cyperoideae. Adansonia 13: 145-171.

- 1977. Notes Cypérologiques: 31. Mélanges nomenclaturaux (Cyperoideae). Adansonia, ser. 2 17: $43-47$. 
Roalson, E. H. \& E. A. Friar. 2000. Supraspecific classification of Eleocharis (Cyperaceae) revisited: evidence from the internal transcribed spacer regions (ITS) of nuclear ribosomal DNA. Syst. Bot. 25: $323-336$.

Simpson D. A., A. M. Muasya, M. Alves, J. J Bruhl, S. Dhooge, M. W. Chase, C. A. Furness, K. Ghamkhar, P. Goetghebeur, T. R. Hodkinson, A. D. Marchant, R. Nieuborg, A. A. Reznicek, E. H. Roalson, E. Smets, J. R. Starr, W. W. Thomas, K. L. Wilson \& X. Zhang. 2007. Phylogeny of Cyperaceae based on DNA sequence data-a new $r b c L$ analysis. Aliso 23: 72-82. In J. T. Columbus, E. A. Friar, J. M. Porter, L. M. Prince \& M. G. Simpson, (eds.), Monocots: comparative biology and evolution, RSABG, California.

Soros, C. L. \& J. J. Bruhl. 2000. Multiple evolutionary origins of C4 photosynthesis in Cyperaceae, pp. 629-636. In K. L. Wilson \& D. A. Morrison, (eds.), Monocots: systematics and evolution, CSIRO Publishing, Melbourne, Victoria, Australia.

Stock, W. D., D. K. Chuba \& G. A. Verboom. 2004. Distribution of South African C3 and C4 species of Cyperaceae in relation to climate and phylogeny. Austral. Ecology 29: 313-319.

Swofford, D. L. 2002. PAUP*: Phylogenetic Analysis Using Parsimony (*and other methods), version 4. Sinauer Associates, Sunderland, MA, USA.

Van der Veken, P. 1965. Contribution à l'embryographie systématique des Cyperaceae-Cyperoideae. Bulletin du jardin botanique de l'État à Bruxelles 35: 285-354.

Vrijdaghs, A., P. Goetghebeur, A. M. Muasya, P. Caris \& E. Smets. 2005. Floral ontogeny in Ficinia and Isolepis (Cyperaceae), with focus on nature and origin of the gynophore. Annals of Botany 96 : $1247-1262$.

— - E. Smets \& A. M. Muasya. 2006. The floral scales in Hellmuthia (Cyperaceae, Cyperoideae) and Paramapania (Cyperaceae, Mapanioideae), an ontogenetic study. Annals of Botany 98: 619-630.

Wilson, K. L. 1981. A synopsis of the genus Scirpus sensu lato. (Cyperaceae) in Australia. Telopea 2: $153-172$.

Yano, O. \& T. Hoshino. 2005. Molecular phylogeny and chromosomal evolution of Japanese Schoenoplectus (Cyperaceae), based on ITS and ETS 1f sequences. Acta Phytotax. Geobot. 56: 183-195.

, \& T. Katsuyama, H. Tsubota \& T. Hoshino. 2004. Molecular phylogeny of Japanese Eleocharis (Cyperaceae) based on ITS sequence data, and chromosomal evolution. J. P1. Res. 117: 409-419. 